\title{
Thomas Mathiesen, Dr. Soc.
}

Nekrolog

\author{
Av Paul Larsson
}

Thomas Mathiesen gikk bort den 29nde mai i år. Med det mistet vi en av Norges mest kjente samfunnsforskere internasjonalt, en kriminalpolitisk kjempe og akademiker av rang. Hans bøker er oversatt til en rekke språk, han var æresdoktor ved Lund universitet og er nevnt sammen med Nils Christie i boken Fifty Key Thinkers in Criminology. Ikke verst av en rettssosiolog.

Thomas Mathiesen ble født den 5 oktober 1933. Med ambisjoner om en karriere som klassisk pianist påbegynte han sine studier i musikk ved University of Wisconsin i 1953. Mathiesen penset raskt over til samfunnsvitenskapen og flyttet tilbake til Norge med en BA i sosiologi i 1955. I 1958 avla han sin magistergrad, senere ble han vitenskapelig assistent for Vilhelm Aubert som ofte nev-

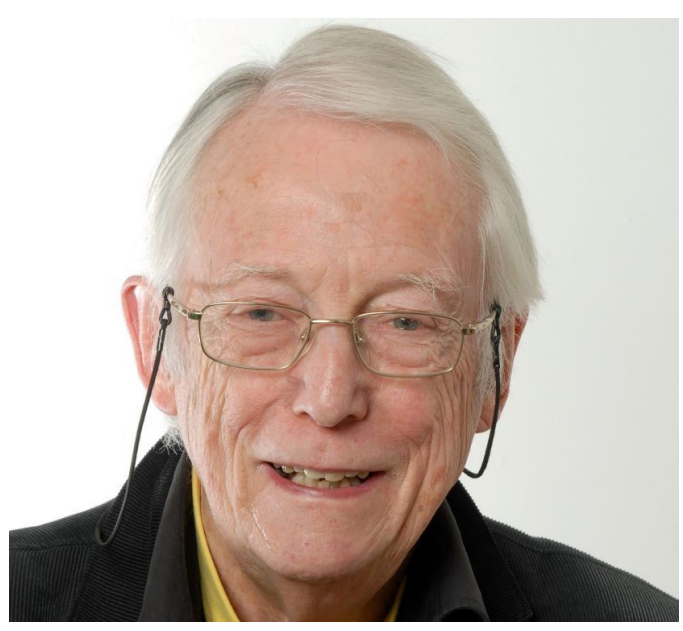

Thomas Mathiesen 1933-2021 (foto: P.J. Ystehede) nes som mentor.

Hans doktorarbeide The Defences of the weak (1965) byggde på studier fra Ila sikringsanstalt. Den etablerte Mathiesen som en av klassikerne innen norsk sosiologi og kriminologi. The Defences of the weak kan leses i forlengelse av internasjonale studier av fengselskulturer som The Society of Captives av Gresham og Sykes, men også Lysgaards studie Arbeidekollektivet. Mathiesen fant i motsetning til sine angloamerikanske kollegaer ingen kollektiv tilpasning på lla, men snarere ulike individuelle og mer sårbare løsninger. Boken siteres fortsatt ofte.

Mellom 1969 og 1972 var han forskningsleder ved Institutt for samfunnsforskning. Siden 1972 professor i Rettssosiologi ved juridisk fakultet ved Universitetet i Oslo. Mathiesen ga norsk rettssosiologi, hvor Vilhelm Aubert var den første professor fra 1963 - 71, en noe annen retning enn i mange andre land. Rettssosiologien kom ofte å ligge tett opp mot faget kriminologi. Han førte nok også faget nærmere sosiologien enn rettsvitenskapen.

Det er likevel innen kriminalpolitikken Thomas Mathiesen gjorde seg mest bemerket. Kanskje er det feil å hevde det, for skillet mellom kriminalpolitikk og akademia ble langt på vei utvisket hos Mathiesen. Mest kjent er han for å ha vært med å starte KROM i 1968 hvor han forble aktiv resten av sitt liv. Han var en uttrettelig stemme i kampen mot bruk av fengsel. Han var abolisjonist og arbeidet for avvikling i bruk av fengselsstraff. Mathiesen og KROM kjempet mot og var med på å dokumentere skadevirkningene av ulike særreaksjoner, som bruken av sikring. Fengsel kunne ikke forsvares, det er kortversjonen av 
hans bok Kan fengsel forsvares? (1987) En annen kampsak gjaldt bruken av straff mot offentlig beruselse i løsgjengerloven. Dette rammet sosialt svært skjevt og tilbakefallet var skyhøyt. Det var så visst ingen »behandling«. Straffen ble opphevet i 1970 etter betydelig offentlig debatt - selve løsgjengerloven ble først endelig opphevet 2006. Mathiesen var sentral i disse og flere andre kriminalpolitiske stridsspørsmål på 1970 tallet, han var en tydelig stemme som talte de marginaliserte og utstøttes sak. Med dette utgangspunktet skulle en tro at KROM kom til å bli en organisasjon som ikke ble lyttet til i maktens korridorer, slik ble det ikke. KROM har i stedet, kanskje særlig gjennom sine årlige seminarer som samler alt fra innsatte til ledende politikere og byråkrater innen justissektoren, hatt en betydelig påvirkning på norsk kriminalpolitikk. Thomas Mathiesens posisjon i KROM var ubestridt.

Politi og overvåkning er blant de temaer som også Mathiesen behandlet i flere bøker, særlig fra slutten av 1970 tallet av. Og de to går ofte over i hverandre. Når Foucaults Surveiller et punir kom på norsk to år etter sin utgivelse oversatt av Dag Østerberg, var det Thomas Mathiesen som skrev forordet. På norsk fikk førsteutgaven den noe merkelige tittel Det moderne fengsels historie (1977). Mye av hva Mathiesen presenterer i forordet, om overvåkningen som en forlengelse av disiplineringsteknikkene utviklet og spredt fra fengselsinstitusjonene med det panoptiske prinspippet som det bærende, utvikler han i en rekke arbeider som kommer i tiårene etter.

Fra tidlig 90-tall kom han til å rette mye av sin oppmerksomhet rundt Schengen og overvåkningen som ble utviklet med de ulike registrene og overvåkningssystemene i EU. Det var særlig SIS - Schengen Information System som var tema i bøker som Schengen: politisamarbeid, overvåking og rettssikkerhet i Europa (1997) og Siste ord er ikke sagt: Schengen og globaliseringen av kontroll (2000). Med dette satte han søkelys på grunnleggende spørsmål rundt overvåkning, rettssikkerhet og kontroll og mulige konsekvenser av systemene som ofte ble glemt ellers i den offentlige debatt.

Thomas Mathiesen hadde et omfattende forfatterskap med mer enn 30 bøker som gikk et godt stykke utenfor de tema som her er nevnt. Mange av oss har lest både Retten og samfunnet (1977) og Retten i samfunnet (1984) som innføringsbøker i rettssosiologi. I mange av hans arbeider er han skarp og ytterst kritisk. Akademia har en plikt til både å si i fra og å søke å bedre forholdene, særlig for marginaliserte og ustøtte. Aksjonsforskning med et nedefra perspektiv og en praktisk rettet rettssosiologi var et ideal. Mathiesen har gjennom ikke bare sitt engasjement og forskning forandret mange av oss, han var også et åpent og ytterst vennlig menneske. Som flere har påpekt så stod alltid hans dør åpen. Han hadde tid til en prat om også forhold som lå et stykke utenfor de vanlige akademiske markene.

Kriminologien og rettssosiologien har, som akademia og samfunnet forøvrig, forandret seg de senere tiår. Deler av denne utviklingen har klart beveget fagene noe bort fra den mer tydelige aktivisme. Rent personlig liker jeg best 
de arbeidene hvor Mathiesen slipper litt taket på det kriminalpolitiske som i hans lille studie fra 1989 Skjellig grunn til mistanke? - En studie av forhørsretten. Nekrolog Her trer den åpent nysgjerrige samfunnsforskeren frem. Hva er det som skjer i forhørsretten? Hvordan er dramaturgien? Hva kommer frem i retten og hvor lang tid får hver sak? Studien dokumenterer uten store ord at forhørsretten nærmest er en maskin, sakene er stort sett avgjort på forhånd og det er ikke mange minuttene til rådighet. Denne nøkterne saklige gjennomgang av rettens realiteter gjorde sterkere inntrykk på meg enn de mer retoriske utspillene. Thomas Mathiesen har utvilsomt preget norsk kriminalpolitikk sterkt i mer enn 50 år. Likevel vil nok mange av oss som hadde med ham å gjøre faglig mer huske hans åpenhet, hans lune - noe tørre - humor og hans interesse for de mer dagligdagse og medmenneskelige sidene av livet. 